\title{
Vanasõnad pedagoogilises kõnes ${ }^{1}$
}

\author{
Liisa Granbom-Herranen
}

Teesid: Käesolev artikkel keskendub vanasõnade ja pedagoogiliste võimaluste vahekorrale laste kasvatamisel. Uurimus käsitleb elulugusid, mis räägivad lapsepõlvest 20. sajandi alguse Soomes. Olen uurimuses kasutanud Soome Kirjanduse Seltsi rahvaluule arhiivi kahte materjalikogumit. Pedagoogilistes kõnedes kasutatavate vanasõnade teemad olid: 1) oma elu kontrollimine ja elamine koos teistega; 2) töö; 3) elatis, tugi ja hooldamine; 4) kristlik eluviis; 5) kontekstita vanasõnad. Kokkuvõtteks võib öelda, et laste silmis tähendavad vanasõnad eri olukordades inimeste, emotsioonide ja teabe kombinatsioone sotsiaal-kultuurilises kontekstis. Lapsel kui kuulajal on vanasõna sisu eelkõige seotud sündmuse ja isikuga. Lapse silmis näib vanasõna olevat esmane konkreetne nõuanne.

Märksõnad: lapsepõlv, pedagoogiline kõne, vanasõna

Artikkel käsitleb lapsepõlves kuuldud kasvatuslike mõjudega vanasõnu. Keelelised sõnumid, näiteks vanasõnad, on kultuurisidusad teated. Argikõne kannab tähendust ka neil puhkudel, mida me ei pea õppimissituatsiooniks. Vanasõnade kuulmise, õppimise ja kasutamise enesestmõistetavus teeb neist kollektiivse teadmise laadsed üldlevinud juhtnöörid. Vanasõnade abil annavad lapse elukäigu esimesed autoriteedid talle eluks vastuvaidlematuid ja küsitavusi mittesisaldavaid juhtnööre.

Pärimusainesest selgub, et pedagoogiliste kõnede mõju ei ole tingimata olnud selline, mida on kasvataja soovinud. Täiskasvanuna vanasõnu kasutades tugineme lapsepõlves omaksvõetud vanasõnatõlgendusele.

Vanasõnad on lausungid, mida ei saa seada kahtluse alla. Sageli liidetakse vanasõnadele oma kujutluses ülevus ja endiste aegade sõnumite sümboolika. Lapsel seda eelootust siiski ei ole. Alles täiskasvanuna otsitakse vanasõnadest võimalikke võrdlusi. Meenutaja räägib eluloos: “Maja elab omas kombes, külaline tuleb omal ajal' tähendas ja tähendab ka minu kodus seda, et kui külaline tuli toiduajal, kaeti talle lauas koht ning toitu jagus ka võõrale. 
Ei mingit peent kostitust, vaid päris tavaline igapäevaroog" (SKS.KRA.PE 9138-9724,1985/1929/N)2.

Kasvatuslikud sündmused juhtuvad kõige sagedamini argiolukorras. Keskendun 20. sajandi alguses kogetud lapsepõlvele ja sellele, kuidas meenutajad käsitlevad vanasõnade kasvatuslikku mõju. Allikmaterjaliks on Soome Kirjanduse Seltsi rahvaluulearhiivi kaks andmekogu, mille elulugudes leidub lapsepõlvesündmuste kirjeldusi. Neist osa on seotud vanasõna(de) ja meenutaja jutustusega sellest, mida ta on kogenud vanasõnade otstarbest. Materjalile kohandatav uurimuse eelootus kinnitab: elulugudes leidub kirjeldusi vanasõnade kasutamise kontekstist.

Neist saab välja lugeda ka midagi lapse kombest kuuldut tõlgitseda ja sellele tähendust anda. Artiklis keskendun otsuste metoodilisele uurimisele.

\section{Uurimuse lähtekohad}

Kasvatus (upbringing) on vanasõnade üks kasutusfunktsioone. Varasemates pedagoogilistes väljaannetes on otsitud vanasõnadest kasvatuslikke eesmärke ja kasvatuslikku kasutust on nähtud kristalliseeruvana vanasõnades (nt Wilska 1948; Ruoppila 1954; Hämäläinen-Forslund 1988, millele toetutakse kasvatuse hindamisel edaspidi; ka Katvala 2001; Kemppiainen 2001; Perälä-Littunen 2004). Soome rahvusliku kasvatuse uurimise keskseks allikaks on olnud Matti Wilska uurimus Kansanomaisesta kasvatuksesta (Rahvuslikust kasvatusest) (1948). Teos sisaldab ka lapsepõlvega seostuvaid vanasõnu.

Wilska järeldused põhinevad peamiselt pärimusjuttudel ja just mainitud mälestusjuttudel. Peale selle tugineb ta järeldustes rahvaluulele ja vanasõnadele. Teise rahvapärast lastekasvatust käsitleva uurimisena on üldist kasutamist leidnud Veikko Ruoppila Kansa lasten kasvattajana (Rahvas oma laste kasvatajana) (1954). Teose läbiv teema on laste kasvatamise seletamine vanasõnade abil. Ruoppila otsib vanasõnadest vastuseid küsimustele, kuidas ja miks last kasvatati. Nii Ruoppila kui ka Wilska selgitavad kasvatuse eesmärke ja kasvatusvõtete rakendamist vanasõnadega. Kodus kasvatamist käsitlevates uurimustes esineb lastekasvatuse ja vanasõnade allikana sageli teos Maammon marjat (Hämäläinen-Forslund 1988). Raamat ühendab folkloori ja väikeste laste kasvatamise. Teos ei näi olevat teaduslikuks kasutuseks ja seda ei tohi sellisena ka käsitleda. Valitsenud tavade kontrollimine vanasõnade (või rahvaluule, rahvalaulude) abil on kaheldav. See, et mõnda vanasõna on teadete kohaselt kasutatud mingil ajal ja seoses mingi kohaga (aeg ja ruum), ei tähenda, nagu oleks keegi toiminud vanasõna sõnasõnalise või sümboolse tõlgenduse kohaselt. 
Peamine uurimist mõjutav tausteeldus on reaalsuse mõistmine. Minu uurimuse aluseks on maailm ja selle kogemine. Küsimus on eelkõige selles, millisena maailm ja selle nähtused silmadele avanevad ja millisena seda kogetakse. (Varto 1995: 70). Tähendused kujundavad inimese eluilma. Need moodustuvad inimese ja üldise kultuuri vastastikustes mõjudes. Markku Satulehto (1992: 23) kohaselt nimetab filosoof Edmund Husserl seda kogetavat maailma eri seostes elumaailmaks, argikogemuste maailmaks, vahetu kogemuse maailmaks või loomuliku seisundi maailmaks. Inimene loob oma elamise kaudu nii sündmuste kui ka nähtuste tähendusi. Et üldjuhul elab inimene mingis koosluses (ühiskonnas) ja on selles valitseva sotsiokultuurilise keskkonna osa, kujundavad üksikisiku arusaamad ka ühiskonna arusaamu. Sellest järeldub, et teave ja arusaamad on seotud ajastu - nii praeguse kui ka eelmise - loodud tõlgenduste ja tähenduste omistamisega. Teadmistepõhine vanasõnade tähtsuse hindamine tugineb meenutajate kogemusele endast ja eluilmast. Individuaalne kogemus toimib ühiskonnaga jagatud aegruumis. See, kuidas tõde mõistetakse, on suunanud uurimuse lähtealuste valimist. Ma ei jaga elulugude valimis esitatud vanasõnade tõlgendusi õigeteks või vääradeks. Inimeste elulugudes käsitletakse nende endi kogemusi ja nende endi antud tähendusi. Selle uurimuse üldtulemused põhinevad nõudel, et individuaalsed eluilmad ja üldistavad järeldused ei oleks vastuolus. On olemas üks maailm, mis avaldub inimeste kogemustes eri viisidel. Üksikindiviidi maailm kujuneb ühiskonna sees. (Granbom-Herranen 2008: 46-47.)

\section{Elulood pajatavad argikasvatuse ajaloost}

Ühiskond määrab, mis on mäletamist väärt. Teisest küljest otsustab ühiskond, mida peab meeles pidama ja reguleerib ka meenutamisviise. Mälestuste tõlgendamisel - nii meenutajate kui ka uurijate seisukohalt - räägivad sotsiokultuuriliste mõjuritena kaasa nii isiklikud kogemused, ühiskondlik arvamus kui ka avalik arutelu. Isikliku ja ühiskondliku lahutamine meenutustest ei ole võimalik. Kuigi mälestus toodab üldjoontes konventsionaalselt seotud jutustust, võib jutustuses näha kogetud elu tõelist esitlust - see ei pruugi olla kogu elu, kuid on osa sellest. (Granbom-Herranen 2008: 57-58.) Põhimõtteliselt püüab meenutaja mäletada õigesti. Mälestustega on võrdselt seotud reaalsustaju ja tunne, et mäletatakse õigesti. Leidub aga mitmeid nähtusi, mis mäluteadetesse ei jõua. Mälestuste rääkija seisukohalt olulisi sündmusi ja inimesi mäletatakse hästi ning neid meenutatakse sageli.

Igal mälestusel ja kirjapandud sõnal on oma sünnikontekst. Nii ka talletatud elulugudel, ja elulugude kirjutamise võistlus toob sinna lisa. Sageli ei ole 
tasuks majanduslik kasu või reklaam, kuid tunnustus on kindlasti innustav jõud. Kui Vilko (1997: 127) kohaselt oma eluloo kirjutajad põhjendavad oma vastuseid ja selgitavad kirjutamisvõistlustel osalemise põhjusi, siis traditsioonide säilitamiseks korraldatud korjandustes ja võistlustes osalemist ei ole vaja põhjendada. Sellel, miks inimene oma eluloo kirja paneb, on mitmeid põhjusi. Üks vanasõnade talletamise olulisimaid motiive on traditsiooni säilitamine ja edasi andmine. Sageli räägivad meenutajad oma soovist talletada traditsioon üheaegselt nii tulevaste põlvede tarvis kui ka arhiveerida see teadlastele uurimistööks. Minu kasutatavad elulugude toimikud, mis sisaldavad pedagoogilises kõnes kasutatud vanasõnu, on avatud kogumiste tulemus: PE85 oli auhinnaline võistukirjutamine, seevastu KE84 puhul ei olnud võistlust ega auhindu. Kummagi kogumise osalisi ei ole valitud. Sellel on nii eeliseid kui ka puudusi. Eelisteks on eelarvamustest ja -ootustest tingitud raamide puudumine, mis võib-olla toob kaasa ka ootamatuid vastajaterühmi. Puudusteks on võimalus, et piirangute tõttu (osaleda võisid ainult põllumehed või teenistujad) moodustub järelduste tegemise seisukohalt liiga heterogeenne ainestik (Roos 1988: 145).

\section{Peamised mõisted}

Kasutatud termin pedagoogiline kõne (pedagogical speech) põhineb folklorist Charles Briggsi vanasõnu sisaldavate juttude kasutamisseostel. Briggsi kohaselt kasutatakse vanasõnu peamiselt kas eakate inimeste omavahelises kõnes võrdse vestluse raames, kuid enamasti vanemate inimeste juttudes noorematega, kus jutul on kasvatuslik eesmärk. Viimasel juhul kasutab Briggs nimetust pedagogical discourse (Briggs 1985: 795; 1988: 22, 104). Briggsi mõistest olen arendanud hariduslikul eesmärgil peetava kõne, millest omakorda olen loonud mõiste pedagoogiline kõne. See tähendab ebavõrdsete inimeste vestlust, kus kuulaja on madalamal võimuastmel. Kui tegemist on lapsepõlves kuuldud vanasõnu sisaldava jutuga, meenutatakse tavaliselt täiskasvanu ja lapse vestlust (peamiselt vanemate ja vanavanematega; mõnikord mainitakse vestluskaaslasena mõnda teist täiskasvanut või meenutaja vanemat venda või õde). Vanasõnade kasutamine argises pedagoogilises kõnes on olnud ja on jätkuvalt pigem vestluses ettetulev seik kui pika kaalumise tulemusel kasutatud tarkus. Üksnes vanasõna põhjal ei saa teada, kas see on olnud osa võrdsest vestlusest või pedagoogiline kõne. Selleks on vaja teada konteksti, mis eristab vanasõna meenutuses selle metakõnelisest kasutamisest. ${ }^{3}$

Teine keskne mõiste on vanasõna (proverb). Vanasõna on oma põhiolemuselt üleüldine teave, millel on oma vorm ja milles sisaldub mingi idee (Taylor 1994: 3). Nagu Ilhan Basgöz (1990: 7) tõdeb, toob iga vanasõna määratlemine kaasa 
rohkem uusi küsimusi kui vastuseid, sest alati leidub midagi, mida tuleks käsitleda midagi kõrvale jätmata ja vastupidi. Vanasõnauurijad on olnud ühel meelel, et vanasõna peamine tunnus on tema lühidus ja seda peetakse mingil määral traditsiooniliseks (nt Seitel 1994: 124). ${ }^{4}$ Folkloristliku määratluse kohaselt sisaldab vanasõna iseseisvat terviklikku mõtet ja on rahva seas üleüldiselt levinud väljend (Apo 2001: 338). Neist "iseseisev terviklik mõte" on mõistetav, aga "üleüldine levik" toob kaasa mõningaid piiritlemisi, ja "rahva seas" eeldab teadvustamist, milline on sihtrühmana silmas peetav rahvas. Kas see on mingi riigi kogu rahvastik, keelerühm või sotsiaalsel kihistusel vms põhinev muu osa rahvastikust. Oluliseks muutub see ühiskonnas, kus sotsiaalsete rühmade jagunemine põhineb keelelisel jagunemisel, nagu oli autonoomia ajal Soomes. Soomekeelsed vanasõnad on keeleliselt olnud peamiselt soomekeelse maarahva ja maalt linna siirdunud rahva pärisosa. (Granbom-Herranen 2008: 116-117.)

Kasutan nimetust vanasõna peamiselt selle folkloristlikus tähenduses, mis sisaldab ka vanasõnalaadseid teateid. ${ }^{5}$ Vanasõna laiemat määratlust toetab meenutajate arusaam sellest, mis on vanasõna. Meenutajad on võrdväärselt käsitlenud kõnekäände, vanasõnu, väljendeid ja piiblitsitaate. Meenutustes ei pruugita mainidagi, et tegu on erinevate liikidega. Teemat käsitledes ei austa ma meenutajate ideed, sest teen vahet kõnekäändudel ja vanasõnadel (vt Kuusi 1954). Mõne teise keele (rootsi, inglise, saksa, hispaania, eesti, araabia) vanasõnade vastete uurimine kinnitas mõiste laia ulatust. Paljudes keeltes segunevad omavahel vanasõnade ja kõnekäändude tõlked. Selles kontekstis ei ole uurimisaines mõiste ise, vaid selle tõlgendus. ${ }^{6}$

Vanasõnad on ühiskonna ajaloo toodetud teated. Uurimuslikke erinevusi on selles, kuidas arvestada tõlgendamisel kultuuri üldkonteksti ja väiksemate üksuste olude konteksti. Peamine nägemuserisus puudutab universaalse tõlgenduse võimalikkust ja õigustatust. Uurimuse raames võib vanasõna tõlgendus põhineda esiteks sellel, mida oletatakse vanasõna üleüldiselt tähendavat. Sellisel juhul annab isiklike kogemuste või eri allikate põhjal olukorrale (või kogu ajastule) tähenduse väljaspool seisev uurija. Teiseks võib välispoolne tõlgendus lähtuda sõna grammatilisest tähendusest. Kolmas võimalus on käsitleda vanasõna kõneleja vaatepunktist olukordades, kus vanasõna kasutaja kavatsused on teada. Neljas vanasõna tähendusele lähenemise võimalus on see, mis jõuab kuulajani, mida kuulaja kuuleb, mõistab ja kuidas seda tõlgendab. Kaks viimast tõlgendusvõimalust eeldavad tähenduse andmise huvides kasutamiskonteksti tundmist.

Iseenesest võib vanasõnateateid uuriv tõlgendus ilma kasutamisolukordi teadmata suuresti erineda vanasõna kasutava üksikisiku või rühma antavast kasutustõlgendusest. Soome vanasõnade uurimine on suures osas keskendunud vanasõnade variatsioonidele ning nende vanuse ja leviku uurimisele. Vanasõnu 
kasutavas uuringus on osalise vaatepunkt seotud lähtekohaks oleva uurimisainesega. Nii soome vanasõnauurimine (objektiks vanasõna nii keeleteaduses kui ka folkloristikas) kui ka vanasõnu kasutav uurimine (objektiks vanasõnade sisu uurimine nt kasvatusteaduslikes, sotsiaalpsühholoogilistes, teoloogilistes või majandusteaduslikes uurimustes) tugineb peamiselt nende oletatavale üldtunnustatud tähendusele (standard proverbial interpretation, SPI). Oletatava üldtunnustatud tähenduse lähtepunktiks on asjaolu, et vanasõnu kasutatakse automaatselt ja korduvalt tähenduses, mis on tuttav kõigile inimestele (Norrick 1985: 1). Äärmuseni viidud üldtunnustatud tähendus sisaldab ideed, et nii vanasõna kui ka selle tõlgitsemine ja tähendus on universaalne ning kehtib nii aja kui ka ruumi suhtes. Küsimus on vanasõna eesmärgis ja vanasõnadele antud tähenduse tõlgitsemises, mitte eriteate (vanasõna) identifitseerimises eeldatava kokkulepitud määratluse põhjal. (Granbom-Herranen 2008: 172-174.) Metafoorid on kasvatusteaduslikes uurimustes olnud olulisemad kui vanasõnad (nt Gordon \& Lahelma \& Tolonen 1995; Auranen 2004; Nummenmaa \& Lautamatti 2004). Metafooride tähenduse analüüs toetub üldisele arvamusele, et on olemas igas olukorras sobiv üldtähendus.

Mälestusjutustus on abiterminite kolmas allikas. Kesksed on elulugu (life story) ja meenutus (narration). Elulugu sel põhjusel, et oma elu sündmustest jutustaja teeb oma elu mõistetavaks mälestuste kaudu. Omaenda lugu kujundab inimene kogu elu. Elulood on "katkematud jutustused" (Ukkonen 2000: 34), mida võib rääkida mis tahes eluetapil. Elulugu tähendab vabas vormis isiklikku jutustust ja see on algupäraselt suuline narratiiv. See on jutustus oma elust või mingist sündmusest, mida inimene peab oma elu tähelepanuväärseks osaks. Termin elulugu on paindlik, see ei eelda täielikkust ega sellist kõikehaaravust nagu autobiograafia. (Titon 1980: 276-277; Siikala 1984: 142-143.)

Elulugu sisaldab nii täies mahus isiklikke kogemusi kui ka meenutaja eluga lähedalt seotud sündmusi ja kogemusi, kuhu kuuluvad ka pere ja suguvõsaga seotud jagatud meenutused. Need ei pruugi olla sündmused otse meenutaja oma kogemusmaailmast, kuid on sellega seotud sama kindlalt, nagu oleks ta need ise läbi elanud. Mälestus võib olla jutustatud või kirjutatud meenutus. ${ }^{7}$ Siin on teemaks kirjapandud mälestus. Igasugune mälestus tähendab mineviku meenutamist ja jutustamist, jagamist teistega, mis üldjuhul viitab autobiograafilisele jutustamisele. Mälestused moodustuvad aja ja elu jooksul. Kuid kogemuste tõlgendus või kindlale mõistele (nagu vanasõna) antud tähendus üldiselt mälestustes ei muutu. Lapsepõlvemälestustes on kohal nii jutustaja lapsepõlves kui ka mälestuse esitamise ajas. Näide 1, väljavõte episoodist (SKS. KRA.PE 11993-12144.1985/1923/N):

Aga isegi kui kirikusse poleks mindud, peeti kinni nõudest "sina pead pühapäeva pühitsema”. Ja tänapäevani olen valmis alla kirjutama vara- 
kult õpitud tarkusele: "pühapäine töö argipäeva ei aita". Ma ei tee leiba, ei küpseta, ei korista, ma ei tee isegi käsitööd pühapäeval. Aga on tähelepanuväärne, et keeld ei tundu käivat kirjutamise kohta, kuigi just see on aastakümneid olnud minu töö! Katsete kontrollimine ja kogumine, üleskirjutamine, fotode kleepimine jne ei kutsunud esile ka ema halvakspanu.

\section{Materjalide töötlemine}

Kasutatav jutustav materjal pärineb Soome Kirjanduse Seltsi (SKS) rahvaluule arhiivi kogudest. Kogud on "Perinne elämässäni, Kalevalan juhlavuoden kilpakirjoitus" (Traditsioon minu elus, Kalevala aastapäeva võistukirjutamine) 1985. aastal (PE85), lisaks "Karjalaiset elämäkerrat" (Karjalaste elulood) kogumine aastatest 1983-84 (KE84), mille ülestähendused sarnanevad kirjutatud mälestustele. Nende elulugude uurimine meenutab vestlust. Mälestus on lähtunud konkreetsest teemast. Vanasõnad esinevad koos muu jutustusega. Vanasõnadesse suhtumine pärineb kuulaja lapsepõlvest, aga täiskasvanu meenutustes.

PE85 andmestikule sattusin seoses folkloristika süvaõppega. See materjal tõestas, et ka Soome ainestikus leidub kontekstiga seotud vanasõnu. Samas selgus, et vanasõnakasutuses võib jälgida kahte keskset valdkonda: kasvatuslikud olukorrad ja vanasõnade retooriline kasutus, nagu Briggs (1985; 1988) sõnastab. PE85 võistukirjutamisest saadud kogemusele tuginedes laiendasin uurimust KE84 kogumisele. Mõlema kogumise puhul olen uurinud ainult kirjapandud tekste.

\begin{tabular}{|l|l|l|l|}
\hline Kogumine: & PE85 & KE84 & Kokku \\
\hline & 108 köidet & 172 köidet & \\
Maht: & 19 300 lehekülge & 22784 lehekülge & 42 084 lehekülge \\
& 16 tundi helilinte & 325 tundi helilinte & 341 tundi helilinte \\
& 487 annetajat & 793 meenutajat & 1226 inimest \\
\hline
\end{tabular}

Tabel 1. PE85 võistukirjutamise ja KE84 korjanduse materjalide kokkuvõte. ${ }^{8}$ 
Materjalide töötlemine algas kogumiste (PE85 ja KE84) kõigi vastuste läbilugemisega. Olen piiritlenud materjalid, et katta kogu KE84 kogumise ja PE85 võistukirjutamise teemad 1 ja 5 . Teises etapis otsisin kogumismaterjalidest välja kõik vanasõnu sisaldavad elulood. Sellele järgnes tõsisem tutvumine elulugudega. Korjasin välja tekstid, kus meenutaja oli lisanud vanasõnu lapsepõlvest, mil ta ise oli peamiselt kuulaja rollis. Jagasin jutustajad sünniaasta põhjal 1929. aastal ja varem sündinud vastajateks, võttes uurimise alla 20. sajandi algusaastate lapsepõlve ja aja enne Teist maailmasõda. 1930. aastate algus oli samuti kogumistel meenutanute vanuselise struktuuri poolest tähendusrikas. (Granbom-Herranen 2009: 155-156.)

\begin{tabular}{|l|l|l|l|}
\hline & PE85 & KE84 & Kokku \\
\hline Valitud teemad & $\begin{array}{l}\text { Kodu ja sugu (Ks) } \\
\text { Soorollid ja } \\
\text { abieluks valmis- } \\
\text { tumine (Sr \& Ka) }\end{array}$ & $\begin{array}{l}\text { Kogu kogutud } \\
\text { materjal }\end{array}$ & \\
\hline Elulugude arv & $\begin{array}{l}280 \mathrm{Ks} \\
158 \mathrm{Sr} \& \mathrm{Ka}\end{array}$ & 722 & $1160^{9}$ \\
\hline $\begin{array}{l}\text { Neist vanasõnu } \\
\text { sisaldavaid (tk) }\end{array}$ & 160 & 192 & 325 \\
\hline $\begin{array}{l}\text { Neist enne 1930 } \\
\text { sündinud jutus- } \\
\text { tajaid }\end{array}$ & 80 & 61 & 141 \\
\hline $\begin{array}{l}\text { Neis vanasõnu } \\
\text { kokku (tk) }\end{array}$ & 367 & 141 & 508 \\
\hline
\end{tabular}

Tabel 2. Uurimuse andmestik (Granbom-Herranen 2008: 60).

Elulugudes vaatlesin lapsepõlvesündmusi kajastavaid episoode, mis sisaldasid sündmusega seotud pedagoogilises kõnes kuuldud vanasõnu ning tõlgendusi, mis meenutajad neile vanasõnadele lapsena andsid. Kuulaja poolt vanasõnale antud tõlgenduse (tähenduse, mõtte) väljaselgitamine algas elulugude vanasõnu sisaldavatest episoodidest. Vaatluse all on olnud vanasõna ning sellega seotud tõlgendus ja kasutamiskontekst. Autobiograafia sobivusteooriat (Vilkko 1997: 22-25) järgides püüdsin aru saada - mitte tõlgendada - meenutatavast, jättes kõrvale vanasõnade oletatava üldtähenduse. Alustasin meenutajate kujutatud olukordades kasutatud märksõnade (tõlgenduste) otsimisest. Jagasin pedagoogilise kõne vanasõnadega pikitud näited meenutajate endi tõlgenduste 
alusel teemadeks (kuigi meenutaja tõlgendus filtreerub alati uurija tõlgenduse kaudu). Omavahel liituvad teemad rühmitasin.

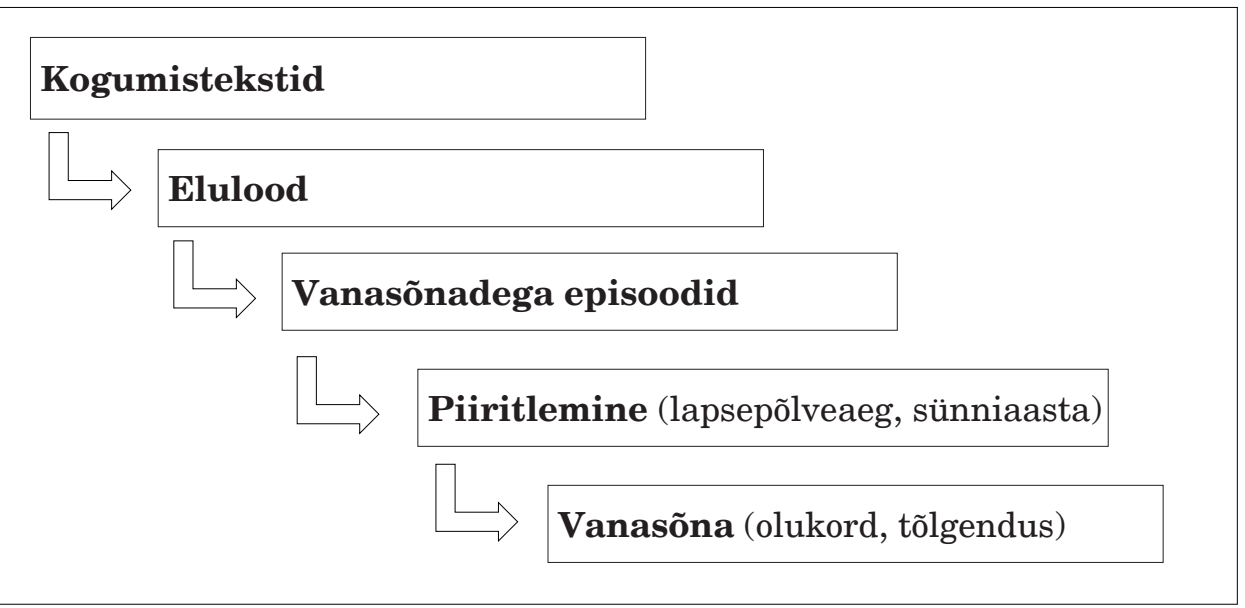

Joonis 1. Materjali käsitlemise etapid.

Rühmadest moodustasin neli teemat, mis katavad 414 vanasõna tõlgenduse kokku 508 vanasõnast. Kõige rohkem vanasõnu sisaldab teema "Oma elu juhtimine ja teistega koos elamine" (143 vanasõna). Teised teemad on "Töö, töötegemine, töötegija” (119), "Elu ja hoolitsus, kodu ja kasvatus" (95) ja "Kristlikud elukombed ja kirjaoskus" (57). Lisaks on 94 vanasõna, millele ei ole tekstides tõlgendust antud. Need metakõnelised vanasõnad on jäetud käsitlusest kõrvale. Neid on mainitud lapsepõlves kuulduna ja meeldejäänuna, kuid meenutaja ei ole oma eluloos neile tõlgendust andnud.

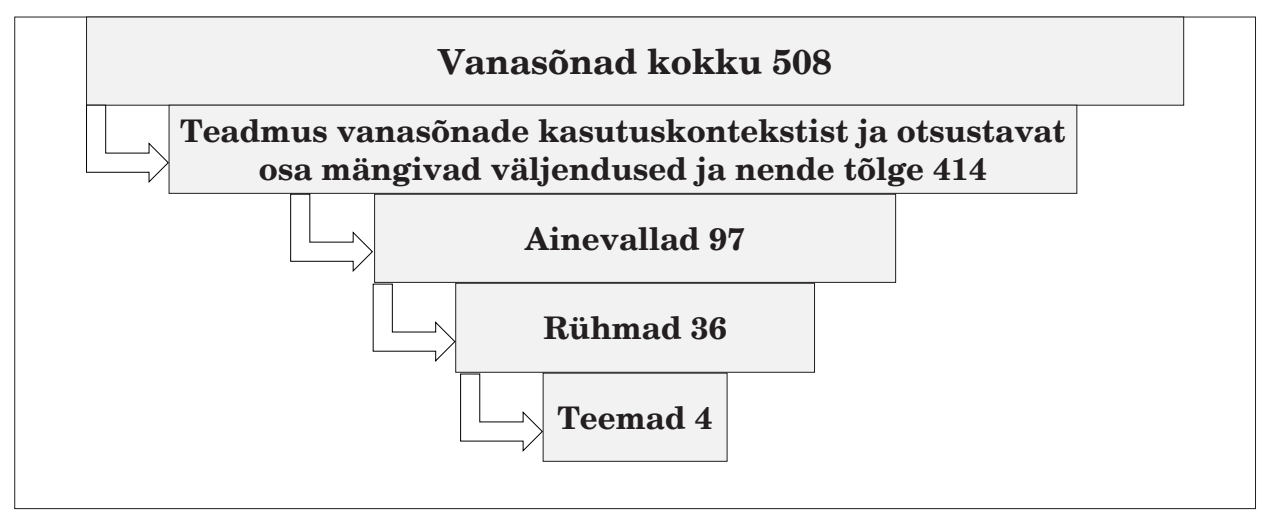

Joonis 2. Rühmitamise käik. 
Näide 2, väljavõte episoodist (SKS.KRA.PE 2850-2926.1985/1914/M):

Et minu vanemad ei ole kunagi olnud rahulolematud oma majanduslike oludega, on nad kogu aeg rõhutanud, et inimene peab ise suutma luua oma elu ja tulevikku. Isa väljendas seda vanasõnana: "Ega keegi teise lusikale puhu."

Meenutaja tõlgenduse seisukohalt sisalduvad märksõnad lauses "inimene peab ise suutma luua oma elu ja tulevikku". Tõlgendus paigutub teemasse "vastutus oma elu eest". See teema omakorda kuulub rühma, mis jääb teemasse "Oma elu juhtimine ja teistega koos elamine".

\section{Isad, raamatud ja mõned muud tähelepanekud}

Selle materjali vanasõnu sisaldavad meenutused kirjeldavad lapsepõlve, kus vanemad on olemas, kuigi nad ei ole alati füüsiliselt lapse kõrval. Vanasõnu sisaldavast materjalist ei aimdu vanematega seotud mälestuste vähesust, millele viitas Vilkko (1997: 200-222). Materjali hulka on arvatud küll üksnes vanasõnu sisaldavad mälestused. Pedagoogilise kõne vanasõnad ei iseloomusta meenutaja sugu, oluline on hoopis neid kuulev laps. Peredes on isa kasvatuslik roll seotud peamiselt töötegemisega ja tööoskuste õpetamisega just poistele. Teisalt on patriarhaalse mudeli kohaselt väidetud, et isa on kandnud hoolt laste kristliku kasvatuse eest. ${ }^{10}$ Isa ja teiste meeste tähtsust ja osalemist eelkõige väikeste laste kasvatamisel üleüldse on materjalis peetud väheseks. Materjali põhjal ei seostata töö harjutamist kuigivõrd isaga. Elulugudes mainitakse tööga seotud vanasõnade ütlejana rohkem ema ja üleüldse on vanasõnade kasutaja olnud sagedamini naine. Nii on see peaaegu igas teises (45\%) kõigist mainitud juhtumitest. Pidades silmas ühiskondlikku arvamust kasvatusvõime kasutamisest, on see üsna huvitav tähelepanek. ${ }^{11}$

Tõlgendustes ei liitu pedagoogilise kõne vanasõnad kohe õppimisega. Ka lugemise tähendus saab elulugude pedagoogilise kõne vanasõnades üsna vähe tähelepanu. Üksikud erandid välja arvatud, ei leidu materjalis viiteid koolile või raamatutele. Ainsana mainitakse piiblit. Selle põhjal on raamatud lapsepõlvemälestuste argikasutuses olnud vanasõnade allikaks harvem kui on varem oletatud, nagu näiteks Apo (1995: 61) ja Siikala (1996: 145). ${ }^{12}$

Vanasõnade kasutamine tähendab ühiskonda kaasamist. Vanasõnu iseloomustatakse ka ühiskondliku traditsiooni üksikisikule kohandatava normina. (nt Alexander \& Hasan-Rokem 1988: 2, 13; ka Basgöz 1990: 12.) Kasvatuse üks oluline eesmärk, mis leidub vanasõnade tõlgendustes, käsitleb ühiskonnas elamist. Tõlgenduste kohaselt on eesmärk kasvatada lapsest täiskasvanu, kes 
suudab elada koos teiste inimestega ja samal ajal iseseisvalt mõelda. Seega ei ole küsimus üksnes normide otseses edasiandmises. Meenutajate tõlgendused materjalides ei toeta seisukohta vanasõnadest kui autoritaarsest normide edasiandmise süsteemist. Doktriinidel põhineva negatiivse kasvatamise tööhüpotees ei leidnud Puolimatka (2001) indoktrinatsioonimääratluse kohaselt kinnitust.

\section{Lapse arusaam vanasõnade kasvatuslikest eesmärkidest}

Elulugudes leidub kirjeldusi lapsepõlves kuuldud vanasõnu sisaldavast kõnest ja meenutajate tõlgendusi kuuldule. Kasvatuslike eesmärkide uurimise seisukohalt võib näha eesmärkide teostumist: elulugude abil võib jõuda lapsepõlves vanasõnale omistatud tõlgenduseni (või eesmärgini). Termin tõlgendus ei pruugi olla siinkohal parim, sest laps tegelikult ei tõlgenda vanasõna. Laps annab vanasõnale mingi tähenduse või eesmärgi, mis kerkib esile, kui inimene räägib lapsepõlvest. Põhiline on meenutaja kogemus, milleks ta tunneb end olevat vanasõnadelt juhendust saanud ja milliste eesmärkide poole leiab end juhitud olevat. Kuulajate tõlgenduste kohaselt teenis 20. sajandi alguse pedagoogiliste kõnede vanasõnade sisu peamiselt 19. sajandi (st kasvataja lapsepõlve) kasvatuslikke eesmärke ja seadusi. Seaduste all pean seaduste ja määruste kõrval silmas ka muid valitsejate nõudeid, ettekirjutusi ja avaldusi. Võib-olla just selle sarnasuse tõttu on vanasõnades nähtud ilmaliku ja vaimuliku võimukõne jätku. Ka on pedagoogilist kõnet ja vanasõnu sageli nähtud võimu seatud kasvatusvõtete kandjaina.

Kasutatava materjali ja lähenemisviisi kombinatsiooni peamiseks tulemuseks pean seda, et kasvatussituatsioonis erineb vanasõna oletatav tähendus (üldtähendus, SPI) vanasõnale omistatud situatsioonitähendusest. Kokkuvõtva järeldusena võib öelda, et eeldatav doktriinidepõhine negatiivne kasvatus ei tundu kasvatatava seisukohalt põhialusena. Kuivõrd lapse vanasõnatõlgendus (vanasõnale antav tähendus või mõte) erineb selle oletatavast üldtunnustatud tähendusest, on küsitavad vanasõnade üldisel tähendusel põhinevad järeldused kasvatuslike eesmärkide saavutamisest (vt nt Ruoppila 1954; Wilska 1948). Lõpptulemusena saab küsitavaks ka üleüldine oletatav seaduspärasus, et vanasõnal on universaalne üldtähendus, mille alusel vanasõna selgitus kehtib eri olukordades. Oletatav üldtähendus ei kehti laste kogemuses (või teises ajas või teises kultuuris). Kuulaja (lapse) arusaam öeldust ja vanasõna tähendusest (käesoleval juhul kasvatuslikust eesmärgist) erineb sellest, mida üldjuhul peetakse selle vanasõna sõnumiks. Tõlgendus, mille laps kuulajana vanasõnale annab, ei ole tingimata see, mida üleüldiselt vanasõna sisuks peetakse. Lapse 
tõlgenduses on pedagoogilise kõne vanasõna lühike meeldetuletus, juhis või kellelegi iseloomulik ütlemine, mis seostub tihedalt tegevuse või sündmusega. Lapse seisukohalt on esmatähtis tegevus. Vanasõna kasvatuslik roll on väljaõppe toetamine. Materjalis ei räägita vanasõnade adutud või tõlgendatud võrdkujulisest kõnest. Järgmises episoodis on näide vanasõna ja käsiloleva konkreetse tegevuse seosest.

Näide 3, väljavõte episoodist (SKS.KRA.KE 11515-11671.1984/1904/M):

Voolusängi põhjas oli väga järsk põhi ja see sügavik oli suurepärane ongitsemiskoht. Vene kinnitati ühest otsast köiega rannapuude külge ja teisest ankruga, et see paigal püsiks ja nii seal õngitseti. Seal võtsid suured ahvenad ja säinad, mõnikord kobe latikaski. See ei takistanud midagi, kui mõni paat tuli või läks, kalad tulid peagi tagasi. Kui kalade võtmises tekkis väike vahe, oli isal varuks mingi laulujupp või rääkida mõnus jutt. Ta ei olnud eriti valmis kohta muutma, vaid kordas tihti vana ütlust "ootavasse õnge kala näkkab”.

Selles näites on ootamine lapsele füüsiline sündmus ja kala elus loom. Võõras või täiskasvanud tõlgendaja kuuleb kõnealuses vanasõnas kergesti sügavat mõtet. See idee võib üldlevinud tähenduse põhjal olla kannatlikkuse kui vooruse rõhutamine õngitsemisel. ${ }^{13}$ Samal ajal ilmneb episoodist, et tegemist ei ole üksnes ühe juhusliku õngitsemiskorraga. Vanasõna õige (ja siis ka ekslik) tõlgendamine on tähenduslik ennekõike vanasõna kasutajale. Kõneleja seisukohalt on oluline, kas vanasõnale omistatud tõlgendus jõuab kasvatatavani. Kasvatajal on kasutatavat sõnumit valides kindel eesmärk. Ütleja isiklik kogemus toetab ka tähendust, mida ta ise on vanasõna mõtteks arvanud ja sellest tuleneb tema enda sõnum. Samuti sõltub ütleja kogemusest kontekst, mis peegeldub vanasõna kasutamisolukordades. (vt Granbom-Herranen 2008: 203-215.)

Ütluse tõlgendamist mõjutab paratamatult tõlgendaja oskus moodustada ja kasutada keelelisi väljendeid ning konkreetse ja abstraktse mõtlemise võime. Samad piirangud (või võimalused) kehtivad ka ütleja kohta. Küsimus ei ole üksnes indiviidi võimes, vaid ühiskonna valmisolekus tervikuna. Asjaolu, et lapse tõlgendus erineb täiskasvanu võimalikust tõlgendusest mõnes teises olukorras, ei muuda lapse tõlgendust vääramaks (või õigemaks) mistahes teistsugusest tõlgendusest. Tõlgenduse lahknevust üldlevinud tähendusest ei saa seletada vanasõna-alase kompetentsi arenematusega. Küsimus on ennekõike uurimuslikus seisukohas, valmiduses leppida valitsevatest ja õigekspeetavatest seisukohtadest erinevate arusaamadega. ${ }^{14}$ Kompetentsi muudab küsitavaks just asjaolu, et lapsepõlvetõlgendus näib saatvat inimest täiskasvanueani. Lapsepõlves vanasõnale antud tähendus kajastub ka täiskasvanueas (nagu 
näites 1). Ka uued ajad ja kasutamisseosed loovad uusi tõlgendusi ja annavad ütlustele uusi tähendusi.

Elulugudes toovad vanasõnade kuuljad esile enda käsituse sellest, kuidas nad kasvatuspüüdlusi tõlgendavad. Nad mõtestavad eesmärki oma kogemusele toetudes. Kuivõrd küsimus on mälestustes, võib tõlgendus sisaldada ka täiskasvanuna omandatud mõistmist. Vanasõna seostub aga olukorra, teema või inimesega nii tihedalt, et meenutaja annab üldjuhul edasi kõnealuse vanasõna lapsepõlvega seotud tõlgenduse. ${ }^{15}$ Lapsepõlves omaksvõetud vanasõna tähendus ja selles sisalduva kasvatusliku eesmärgi mõistmine mõjutab täiskasvanuea arusaamu: seda mäletatakse ja selle juurde naastakse, kui elu käigus kasutatakse ja/või kohatakse kõnealust vanasõna.

Kõne on lapse üks esimestest suhtlusvahenditest. Pedagoogilise kõne vanasõnad on tõhusad ja olulised sõnumid, sest need on lapse elu esimeste autoriteetide sõnad. Seda ilmselgemalt ei tundu vanasõnad lastele vanemate ja vanavanemate sisendatava traditsioonina. Lapsepõlves seostuvad vanasõnadega sotsiaalkultuuriline tegelikkus, inimesed, tunded, aistingud ja vastuvõetav teave. Kuigi üldjuhul mõistavad lapsed kuuldut sõnasõnalt, jääb nende mällu rohkem kui vaid sõnad. Vanasõnad seostuvad teadmiste ja tunnetega. Lapsepõlve vanasõnade jõud ei ole möödunud aegade tarkuses, vaid just vanasõna kõikehõlmavas kogemuses. ${ }^{16}$ Võimalik, et olukord on sama, kui vanasõna kuuldakse esimest korda täiskasvanuna. Täiskasvanul on aga tõlgendamiseks olemas eelnev teave ja kogemus, mida ta saab kuuldu (või loetuga) seostada.

\section{Kokkuvõte}

Minu kasutatav aines pärineb Soome Kirjanduse Seltsi rahvaluulearhiivi kogudest. Kogud on "Perinne elämässäni, Kalevalan juhlavuoden kilpakirjoitus" (Traditsioon minu elus, Kalevala aastapäeva võistukirjutamine) 1985. aastal (PE85), lisaks "Karjalaiset elämäkerrat" (Karjalaste elulood) kogumine aastatest 1983-84 (KE84). Uurimistööd ajendanud eelootus on kinnitust leidnud: elulugudes leidub vanasõnade kasutamisseoste kirjeldusi. Selles kontekstis on oluline asjaolu, kuidas kogeb meenutaja ennast vanasõnadest juhatust saanuna ja millised on olnud kogetud kasvatuslikud eesmärgid. Meenutusi võib käsitleda minevikust jutustavatena ja mitteformaalse kasvatuse uurimise allikmaterjalina. Elulood on mineviku tõlgendused. Meenutused on avalikust mälust erinev üksikisikute ajalugu.

Ametlike ajaloomaterjalide, nagu näiteks koolis käsitletavate dokumentide kõrval võivad mälestused pakkuda silmaringi avardumise võimalust. Mälul põhineva ainestiku kasutamine ajaloolise teabe allikana tõstatab küsimuse 
teadmisest. Mälu ja mineviku tegelikkuse suhe on mäluainestiku peamine allikakriitiline sihtmärk. Tavaliselt on ajaloolise mälu kriitika kontsentreeritud mälu piiratusele ja kultuuritegurite mõjule.

Teised kriitikaobjektid on materjali representatiivsus ja kirjutajate valik. ${ }^{17}$ Uurija enda taustaeeldused, sealhulgas maailmavaade, on andmekesksesse uurimusse sisse programmeeritud. Tõlgendamise käigus peab uurija neid endale teadvustama. Ka uurija esindatav teaduse paradigma suunab kindlasti teemaasetust ja on seotud valikute pertseptsiooniga. Siin kohandub kasvatusteaduslik küsimuseasetus folkloristliku arhiivimaterjaliga.

Individuaalsete eluilmade uurimine iseenesest ei takista üldistusvõimeliste järelduste tegemist. Kogemuste puhul on tegu ühiskonna ja indiviidi kooseksisteerimisega ühises maailmas, mis väljendub inimeste kogemustes erinevalt. Ütluste tõlgendamine on seotud nii individuaalsete kui ka kollektiivsete küpsusastmetega, valmidusega. Oletatav üldtähendus ei kehti laste kogemuses (või teises ajas või teises kultuuris). Lapse tõlgenduses on pedagoogilise kõne vanasõna lühike meeldetuletus, juhis või kellelegi iseloomulik ütlemine, mis seostub tihedalt tegevuse või sündmusega. Lapse seisukohalt on esmatähtis tegevus. Vanasõna hariduslikku rolli võib näha väljaõppe toetamises. On huvitav, et lapsepõlves vanasõnale omistatud tähendus näib mõjutavat teatava vanasõna kasutamist ka täiskasvanueas.

Soomekeelsed vanasõnad on algselt olnud keeleliselt soomekeelse maarahva või maalt linna siirdunud rahva väljendusvahend. Materjalide põhjal on 20. sajandi alguse lapsepõlves soomekeelseid pedagoogilise kõne vanasõnu kuuldud eelkõige naiste kõnes. Võimukasutamise seisukohalt esindavad nad mitmel kombel vähemuse keelt ja kõnet. Silma paistab vastavus avalikele kasvatuspõhimõtetele, kasvatuslikes vanasõnades võib täheldada ühiskondliku ja isikliku mõtteviisi rõhutamist. Pedagoogilise kõne vanasõnad paigutuvad nelja põhiteemasse: 1) "Oma elu juhtimine ja teistega koos elamine"; 2) “Töö, töötegemine, töötegija"; 3) "Elu ja hoolitsus, kodu ja kasvatus "; 4) "Kristlikud elukombed ja kirjaoskus" ning 5) vanasõnad, millega seotud tekstis tõlgendust ei leidu. Tööhüpotees doktriinidel põhinevast negatiivsest kasvatusest minu kasutatud indoktrinatsioonimääratluse kohaselt kinnitust ei leidnud.

Lapse (kuulaja) tõlgendus ei kajasta kasvataja (kõneleja) kavatsusi. Sellele kõige lähem on kuulaja arvamus ütleja kavatsuste kohta. Seda ei saa järeldada elulugudest. Seda käsitlen edaspidi, uurides kasvataja kavatsuste ja indoktrinatsioonide võimalikke kokkulangevusi. Otsin ka vastuseid küsimusele, kas küsimus on üksnes lapse võimes konkreetseid asju mõista või on küsimus kasvataja eesmärkides. Kasvataja eesmärke käsitlen oletatavate üldtähenduste toel. 
Vanemate ja vanavanemate jutu vanasõnadel ei saa praegu olla lapse silmis sama tähtsust, kui oli 20. sajandi alguses, sest lapse argipäev ja kasvamiskeskkond on ju täiskasvanute argielust eraldunud. Laste aeg päevakodudes ja koolides on suuresti lasterühmade kutseliste kasvatajate juhtida, pere ja sugulaskonnaga seotud argipäev ei tähenda enam tihedat sugupõlvede vahelist koostööd. Siiski on pedagoogilisel kõnel - vanasõnadega või ilma - lapse elus keskne koht nii kodus, päevahoius kui kooliski.

\section{Tõlkinud Asta Niinemets}

\section{Kommentaarid}

1 Originaal: Granbom-Herranen, Liisa 2009. Mihin sananlasku lasta johdattaa? Kasvatus \& Aika 3, lk 79-93.

${ }^{2}$ Lühendi selgitus: SKS - Soome Kirjanduse Selts, KRA - rahvaluulearhiiv, PE või $\mathrm{KE}$ - kogumiste lühendid: $\mathrm{PE}$ - perinne elämässäni (traditsioon minu elus) või $\mathrm{KE}$ karjalaiset elämäkerrät - karjala elulood. Leheküljenumbrid viitavad kogude köidete lehekülgedele. Esimene aastanumber märgib, millal on elulugu antud rahvaluulearhiivi ja teine on vastaja sünniaasta (teadmata sünniaasta puhul asendab seda "xxx"). $\mathrm{N}$ või $\mathrm{M}$ tähistab vastaja sugu.

3 Metakõne põhineb Alfred Tarski loodud mõistel metakeel (Raatikainen 1997: 16-17).

4 Vanasõna määratlust käsitleva arutelu kohta vt nt Granbom-Herranen 2004: 7-11; 2008: 35-38; 2009: 153; Lauhakangas 2004: 17-21.

5 Kasvatuslikus mõttes on samas tähenduses kasutatud muuhulgas "vanasõnad ja kõnekäänud" (Ruoppila 1954) ja uuemal ajal "kasvatuslikud uskumused ja ütlused" (Katvala 2001; Kemppainen 2001; Hirsjärvi \& Laurinen 2004; Perälä-Littunen 2004).

6 Perinne elämässäni elulookirjutamise võistluse vastustes esineb vanasõnaga seoses 54 eri nimetust, näiteks väärtus, hoiak, elujuhis, märkus, kasvatuslik eeskuju, nõuanne, üleskutse, ütlus, lause, moto, juhised, õpetlik lause, õpetus, põhimõte, piiblitsitaat, vanasõna, kõnekäänd, ütlus, tõdemus, vana ütlus, tarkus (Granbom-Herranen 2004: lisa 6). Vanasõnade rahvaliku tähenduse kohta vt Basgöz 1990. Käsitletud keeltest kõige huvitavam on ilmselt araabia, kus soomendus sisaldab vanasõnade funktsioonide loetelu. Sõna vanasõna juurtega seotud verbid väljendavad hästi vanasõnade kasutamist, nagu öelda, väita, põhjendada, õpetada, kaitsta, toetada, sõnastada laulu, öelda valesid jne (Granbom-Herranen 2004: lisa 2).

7 Mõistmaks mälestuse-mõiste tausta minu käsitluses vt Granbom-Herranen 2008: 52-59; 2009: 154- 155. Vanasõnade tähendust uurides kõrvutan kirjapandud ja suulisi meenutusi. Kirjapandud meenutus on üleskirjutatud kõne, selle mõiste kohta vt Korkiakangas 1996:94 ja Vilkko 1997: 74.

8 Andmed on kättesaadavad Soome Kirjanduse Seltsi rahvaluulearhiivi materjalidest: Traditsioone minu elus, Kalevala aastapäeva võistukirjutamise tulemused ning Karjala elulookogumise tulemused. 
9 Osa vastanutest oli vastanud nii küsimustikule "Kodu ja perekond" kui ka "Soorollid ja abieluks valmistumine", mistõttu vastanute üldarv jääb tegelikult mõnevõrra väiksemaks kui kahe vastuse summa.

${ }^{10}$ Vt nt Aukia 1984: 165; Waris 1999: 66. Kristluse kasvatamisest vt Kortekangas 1988: 62. Vrd Granbom-Herranen 2004: 63-66; 2008: 149-151.

${ }^{11}$ Kogu kirjutatud elulugude materjalist moodustavad meeste kirjutised napi neljandiku. Enne 1930. aastat sündinute lapsepõlve vanasõnu meenutanud vastanutest on neljandik mehi. Nii Latvala $(2005: 16,19)$ kasutatavas 1997. aastal kogutud "Suvun suuri kertomus" (Suguvõsa suur lugu) materjalis kui ka PE85 võistukirjutuse ainestikus on vanasõnu sisaldavate elulugude ealine jaotuvus proportsionaalne (Granbom-Herranen 2004: lisa 4). Kelle öeldud vanasõnu lapsepõlvest mäletatakse ja miks, on teema, mille põhjal jätkan. Olen seda teemat käsitlenud 2009. aasta suvel kasvatusajaloo päevadel pealkirja all "Vanasõnad ja sugupool lapsepõlvemälestustes".

12 Raamatutest ka nt Kotkanheimo 2002: 52; Lauhakangas 2004: 39-40. Seoses õpetamisega vt Lauhakangas 2005: 132.

${ }^{13}$ Näiteks M6-klassifitseeringus on "ootav õngekala" seotud vanasõnaga "Head asja ei oodata kunagi liiga kaua", mis mõlemad kuuluvad rühma T "Aeg ja aja mõistmine" => $\mathrm{T} 1$ "Õige ajastus / ajakasutus: vale ajastus / ajakasutus => T1h "tasub oodata paremat aega - nõuanne leidub, asjad lahenevad" (Matti Kuusi rahvusvaheline vanasõnade andmebaas www.finlit.fi/aineistot/verkkoaineistot.php - 29. mai 2012).

14 "Valitsev" tähendab valmidust võtta omaks vaid täiskasvanute/kristlaste/ingliskeelsete/ eurooplaste/punapeade vms antud tõlgendus.

${ }^{15}$ Latvala (2005: 171) tähelepaneku kohaselt avaldub lapsepõlve käsitlevas meenutuses lapse kogemus ja seisukoht.

${ }^{16}$ Vanasõna tähenduse kõikehõlmavuse moodustumisest vt Lauhakangas 2004: 13, 65-69; Granbom-Herranen 2008: 203-215.

${ }^{17}$ Kogumistöö üldhinnangut ja andmete kogumise arutelu vt nt Latvala 2005: 24-36; Granbom-Herranen 2004: 35-39; 2008: 54-57, 81-86.

\section{Allikad}

Suomalaisen Kirjallisuuden Seuran kansanrunousarkisto (Soome Kirjanduse Seltsi rahvaluulearhiiv):

Karjalaiset elämäkerrat vuosilta 1983-84 (KE84) (Karjalaste elulugude kogumine aastatest 1983-84)

Perinne elämässäni. Kalevalan juhlavuoden kilpakirjoitus vuodelta 1985 (PE85) (Traditsioon minu elus, Kalevala aastapäeva võistukirjutamine 1985. aastal) 


\section{Kirjandus}

Alexander, Tamara \& Hasan-Rokem, Galit 1988. Games of identity in proverb usage: proverbs of a sephardic-jewish woman. Proverbium: yearbook of international proverb scholarship 5, lk 3-12.

Apo, Satu 1995. Naisen väki. Tutkimuksia suomalaisten kansanomaisesta kulttuurista ja ajattelusta. Helsinki: Hanki ja jää.

Apo, Satu 2001. Viinan voima. Näkökulmia suomalaisten kansanomaiseen alkoholiajatteluun ja -kulttuuriin. Suomalaisen Kirjallisuuden Seuran toimituksia 759. Helsinki: SKS.

Aukia, Markku 1984. Perinteisestä kotikasvatuksesta Suomen maaseudulla. Ojala, Mikko (toim). Varhaiskasvatustutkimus Suomessa. Lastensuojelun keskusliitto 71. Helsinki: Lastensuojelun keskusliitto, lk 163-181.

Auranen, Johanna 2004. Tervanjuontia ja ruusuilla tanssia-metaforatutkimus kasvatustyöstä kuntaorganisaation osana. Joensuun yliopiston kasvatustieteellisiä julkaisuja 97.

Basgöz, Ilhan 1990. Proverbs about Proverbs or Folk Definitions of Proverb. Proverbium: yearbook of international proverb scholarship 7, lk 5-17.

Briggs, Charles L 1985. The Pragmatics of Proverb Performances in New Mexican Spanish. American Anthropologist 87, lk 793-810.

Briggs, Charles L 1988. Competence in performance. The Creativity of Tradition in Mexicano Verbal Art. Philadelphia: University of Pennsylvania Press.

Gordon, Tuula \& Lahelma, Elina \& Tolonen, Tarja 1995. "Koulu on kuin ...” Metaforat fyysisen koulun analysoinnin välineenä. Nuorisotutkimus 13: 3, lk 3-12.

Granbom-Herranen, Liisa 2004. Sananlaskujen käyttäjät ja käyttöyhteys. Sananlaskut käyttökontekstissaan 'Perinne elämässäni'-kilpakirjoituksen aineistossa. Pro gradu-tutkielma. Kulttuurien tutkimuksen laitos. Helsingin yliopisto (http://urn.fi/URN:NBN:fife20051452 - 25. mai 2012).

Granbom-Herranen, Liisa 2008. Sananlaskut kasvatuspuheessa - perinnettä, kasvatusta, indoktrinaatiota? Jyväskylä Studies in Education, Psychology and Social Research 329. Jyväskylän yliopisto (http://jyx.jyu.fi/dspace/bitstream/handle/123456789/18554/9789513931117.pdf?sequence=1 - 25. mai 2012).

Granbom-Herranen, Liisa. 2009. Proverbs from childhood. Proverbium: Yearbook of International Proverb Scholarship 26, lk 151-170.

Hirsjärvi, Sirkka \& Laurinen, Leena 2004. Lempeästi mutta lujasti. Suomalaisia sanontoja ja arkiuskomuksia kasvatuksesta. Helsinki: WSOY.

Hämäläinen-Forslund, Pirjo 1988. Maammon marjat: entisaikain lasten elämää. Porvoo: WSOY. 
Katvala, Satu 2001. Missä äiti on? Äitejä ja äitiyden uskomuksia sukupolvien saatossa. Jyväskylä Studies in Education, Psychology and Social Research 186. Jyväskylän yliopisto.

Kemppainen, Jaana 2001. Kotikasvatus kolmessa sukupolvessa. Jyväskylä studies in education, psychology and social research 190. Jyväskylän yliopisto.

Korkiakangas, Pirjo 1996. Muistoista rakentuva lapsuus. Agraarinen perintö lapsuuden työnteon ja leikkien muistelussa. Kansatieteellinen arkisto 42. Helsinki: Suomen muinaismuistoyhdistys.

Kortekangas, Paavo 1988. Perheenisästä kasvatuslehtoriin. Pyysiäinen, Markku (toim). Kasvatus ja uskonto. Suomalaisen teologisen kirjallisuusseuran julkaisuja 160. Helsinki: WSOY, lk 60-67.

Kotkanheimo, Liisa 2002. Lukemaan oppiminen - aapinen. Katsaus kehitystrendeihin ja funktioihin 1500-1950. Pitkäranta, Inkeri (toim). ABC Lukeminen esivallan palveluksessa. Kansalliskirjaston gallerian julkaisuja 2. Helsinki: Suomen kansalliskirjasto, lk 33-77.

Kuusi, Matti 1954. Sananlaskut ja puheenparret. Helsinki: SKS.

Latvala, Pauliina 2005. Katse menneisyyteen. Folkloristinen tutkimus suvun muistitiedosta. Suomalaisen Kirjallisuuden Seuran toimituksia 1024. Helsinki: SKS.

Lauhakangas, Outi 2004. Puheesta ihminen tunnetaan. Sananlaskujen funktiot sosiaalisessa vuorovaikutuksessa. Suomalaisen Kirjallisuuden Seuran toimituksia 1001. Helsinki: SKS.

Lauhakangas, Outi 2005. Kansanviisautta vai viisautta kansalle. Laaksonen, Pekka \& Knuuttila, Seppo \& Piela, Ulla (toim). Kansanetiikkaa. Käsityksiä hyvästä ja pahasta. Kalevalaseuran vuosikirja 84. Helsinki: SKS, lk 122-136.

Norrick, Neal R 1985. How Proverbs Mean: Semantic Studies in English Proverbs. Trends in linguistic, Studies and monographs 27. Berlin: Mouton.

Nummenmaa, Anna Raija \& Lautamatti, Liisa 2004. Opiskelun työprosessin ohjaus korkea-asteella. Metaforia ja merkityksenantoja. Onnismaa, Jussi \& Pasanen, Heikki \& Spangar, Timo (toim). Ohjaus ammattina ja tieteenalana 3: Ohjaustyön välineet. Jyväskylä: PS-Kustannus, lk 88-103.

Perälä-Littunen, Satu 2004. Cultural images of a good mother and a good father in three generations. Jyväskylä Studies in Education, Psychology and Social Research 239. Jyväskylän yliopisto.

Puolimatka, Tapio 2001. Opetusta vai indoktrinaatiota? Valta ja manipulaatio opetuksessa. Helsinki: Kirjayhtymä.

Raatikainen, Panu 1997. Ajattelu, kieli, merkitys - näkökulmia nykyajan filosofian avainteemoihin. Raatikainen, Panu (toim). Ajattelu, kieli, merkitys. Analyyttisen filosofian avainkirjoituksia. Helsinki: Gaudeamus, lk 9-40. 
Roos, Jeja Pekka 1988. Elämäntavasta elämäkertaan. Elämäntapaa etsimässä 2. Tutkijaliiton julkaisusarja 53. Helsinki: Tutkijaliitto.

Ruoppila, Veikko 1954. Kansa lastensa kasvattajana. Porvoo: WSOY.

Satulehto, Markku 1992. Elämismaailma tieteiden perustana. Edmund Husserlin tieteen filosofia. Filosofisia tutkimuksia Tampereen yliopistosta 33. Tampere: Tampereen Yliopisto.

Seitel, Peter 1994 [1969]. Proverbs: A Social Use of Metaphor. Mieder, Wolfgang \& Dundes, Alan (toim). The Wisdom of many. Essays on the Proverb. Madison (WI): University of Wisconsin Press, lk 122-139.

Siikala, Anna-Leena 1984. Tarina ja tulkinta. Tutkimus kansankertojista. Suomalaisen Kirjallisuuden Seuran toimituksia 404. Helsinki: SKS.

Siikala, Anna-Leena 1996. Suomalaisuuden tulkintoja. Laaksonen, Pekka \& Mettomäki, Sirkka-Liisa. (toim). Olkaamme siis suomalaisia. Kalevalaseuran vuosikirja 75-76. Helsinki: SKS, lk 139-149.

Taylor, Archer 1994 [1962]. The Wisdom of Many and the Wit of One. Mieder, Wolfgang \& Dundes, Alan (toim). The Wisdom of many. Essays on the Proverb. Madison (WI): University of Wisconsin Press, lk 3-9.

Titon, Jeff Todd 1980. The Life Story. Journal of American Folklore 93, lk 276-292.

Ukkonen, Taina 2000. Menneisyyden tulkinta kertomalla. Muistelupuhe oman historian ja kokemuskertomusten tuottamisprosessissa. Suomalaisen Kirjallisuuden Seuran toimituksia 797. Helsinki: SKS.

Varto, Juha 1995. Fenomenologinen tieteen kritiikki. Tampereen yliopisto.

Vilkko, Anni 1997. Omaelämäkerta kohtaamispaikkana. Naisen elämän kerronta ja luenta. Suomalaisen Kirjallisuuden Seuran toimituksia 663. Helsinki: SKS.

Waris, Elina 1999. Yksissä leivissä. Ruokolahtelainen perhelaitos ja yhteisöllinen toiminta 1750-1850. Bibliotheca Historica 48. Helsinki: Suomen historiallinen seura.

Wilska, Matti 1948. Kansanomaisesta kasvatuksesta. Etupäässä Karjalassa tehtyjen tutkimusten mukaan. Pieksämäki: Matti Wilskan säätiö.

\section{Summary}

\section{Proverbs in pedagogical speech}

\section{Liisa Granbom-Herranen}

Key words: childhood, pedagogical speech, proverb

This article focuses on the relationship between proverbs and pedagogical situations in bringing up children. The research deals with the life-stories that speak about the 
childhood in the early 20th century Finland. As research material two collections from the Folklore Archives of the Finnish Literature Society in Helsinki have been used. The themes of the proverbs in pedagogical speech were the following: 1) control of one's own life and living with others; 2) work; 3) livelihood, support and care; 4) Christian way of living, and 5) proverbs without a context. As a conclusion it can be said that for a child proverbs are combinations of socio-cultural contexts, people, emotions and information in various situations. For a child as a listener the content of the proverb is, above all, connected with the situation and the person involved, and it serves primarily as a piece of concrete advice. 